\title{
Trypanosomiasis causing mortality outbreak in Nile tilapia intensive farming: Identification and pathological evaluation
}

\section{Raphael Barbetta de Jesus, Sílvia Umeda Gallani, Gustavo Moraes Ramos Valladão, Gabriela Pala, Thiago Fernandes Alves da Silva, Jaqueline Custódio da Costa, Suzana Kotzent, Fabiana Pilarski*}

São Paulo State University (UNESP), Aquaculture Center of Unesp (CAUNESP), Microbiology and Parasitology Laboratory of Aquatic Organisms, Jaboticabal, São Paulo, Brazil

\section{A R T I C L E I N F O}

\section{Keywords:}

Histopathology

Hemoparasite

Nile tilapia

Parasitosis

PCR

Trypanosoma

\begin{abstract}
A B S T R A C T
Trypanosomes are flagellated parasite protozoans that prey especially on wild fish and have recently been described affecting fish in aquaculture. The present study was carried out during a mortality outbreak of Nile tilapia Oreochromis niloticus reared in net cages. Samples of 10 fish in the finishing phase showing unspecific signs, such as anorexia, skin darkening and gill paleness, were analyzed using hemogram, parasitology, microbiology, histopathology, electron microscopy and molecular identification. For microbiological analysis, the kidney was collected aseptically and cultured on tryptone soy agar for $48 \mathrm{~h}$ at $30^{\circ} \mathrm{C}$. For parasitological analysis, skin, gills, intestinal contents and blood scrapings were examined. Photomicrographs of the parasite were measured. For molecular identification, blood samples were processed and sequenced for amplification of the 18S rDNA gene. Gills, liver, spleen, kidney, heart and intestine were sampled for histopathological processing. The microbiological results indicated that the fish were not infected with bacteria. Scrapings of the skin and gills revealed the massive presence of kinetoplastids, which were also observed in greater numbers than erythrocytes in the blood. Intestines were not affected by endoparasites. The morphometric characteristics indicated the presence of the Trypanosoma genus, which was confirmed in the sequenced samples, where $95 \%$ and $98 \%$ of the identity were Trypanosoma sp. In histopathology, all organs presented different levels of alteration, accompanied by large numbers of the parasite in small and large vessels. The main findings were the description of mast cell infiltrates in the gill and intestine, as well as multifocal aggregates of melanomacrophages in the liver, pancreas, spleen and kidney. Furthermore, the study addresses the newest features of clinical signs of infected fish and possible causes of infestations and compares the diagnosis of this hemoparasite with other hemoflagellates. To our knowledge, this study represents the first outbreak of Trypanosoma in Nile tilapia in South America. The authors warn of possible new cases of trypanosomiasis in aquaculture, recommending possible forms of containment and biosecurity measures.
\end{abstract}

\section{Introduction}

Information about diseases caused by hemoparasites and their impact on fish health is scarce (Lourenço et al., 2014), especially information related to parasites of the genus Trypanosoma. Species of this genus are ubiquitous parasites that can affect both salt and freshwater fish species (Khan, 1977) but mostly in wild environments.

Trypanosoma are described in a large host diversity; they can infect all classes of vertebrates, including reptiles (Marcili et al., 2013), amphibians (Lemos et al., 2013), birds (Svobodová et al., 2015), mammals (Lima et al., 2015) and fish (Kovacevic et al., 2015), and their life cycles involve alternating between host vertebrates and invertebrates, such as annelids (Fermino et al., 2015) and arthropods (Ooi et al., 2015).
However, the complete description of the life cycle of Trypanosoma is not well understood in aquaculture. What seems to be the consensus among researchers is that leeches are the intermediate host for fish trypanosomiasis and that this parasite enters the host through the suction wound (Negm-Eldin and Davies, 1999; Karlsbakk et al., 2005; Hayes et al., 2014; Corrêa et al., 2016). Within the host, this parasite multiplies and is found in large numbers in the bloodstream of the fish and, consequently, affects all organs.

In South America, reports of trypanosomiasis are common in several armored fish species (Eiras et al., 1989; Eiras et al., 1990; D'Agosto and Serra-Freire, 1993; Fujimoto et al., 2013; Lemos and Souto-Padrón, 2014; Lemos et al., 2015; Molina et al., 2016; Corrêa et al., 2016), Petenia kraussii (Grögl et al., 1980), catsharks (Morillas et al., 1987;

\footnotetext{
* Corresponding author at: Via de Acesso Prof. Paulo Donato Castellane, s/n, 14884-900 Jaboticabal, São Paulo, Brazil.

E-mail address: fabianap@caunesp.unesp.br (F. Pilarski).
} 
Silva et al., 2005), and in tuvira (Pádua et al., 2011), highlighting that in all these cases, the hosts are wild fish. The most relevant reports of trypanosomiasis in farmed fish are related to groupers in China (Chong, 2005; Su et al., 2014; Wang et al., 2015), and to our knowledge, only Hamid and Babiker (2011) have reported Trypanosoma infections in cultured Nile tilapia Oreochromis niloticus (Sudan).

Until now, little has been known about the pathologies that strike the hosts of Trypanosoma because it is rare to find an infestation of this parasite in such conditions.

Although most of the fish infected by trypanosomiasis are asymptomatic, the high number of parasites in the bloodstream can severely affect the health of the host, causing anemia, leukocytosis, hypoglycemia, splenomegaly (Islam and Woo, 1991; Su et al., 2014) and a massive reduction of thrombocytes (Fink et al., 2015). All this information is relevant and deserves to be investigated, as these cases can culminate in mortalities and serious economic losses in aquaculture.

To provide new insights and impacts on South America aquaculture, this study mainly approaches the clinical signs, diagnosis and pathogenesis of Trypanosoma sp. infecting one of the most produced fish species worldwide, the Nile tilapia.

\section{Material and methods}

The protocol used in this experiment was in accordance with the Brazilian College of Animal Experimentation (COBEA - Colégio Brasileiro de Experimentação Animal) guidelines and was approved by the Ethics, Bioethics and Animal Welfare Committee (CEBEA Comissão de Ética e Bem Estar Animal) of the FCAV-UNESP-Jaboticabal campus (protocol number 12.383/16).

\subsection{Farming conditions and fish}

The study was carried out during a mortality outbreak of Nile tilapia Oreochromis niloticus farmed in an intensive system (net cages, volume $22.5 \mathrm{~m}^{3}$, and density of $80 \mathrm{~kg} \mathrm{~m}^{-3}$ ) in the Tietê river in the state of São Paulo. Six net cages were affected by the disease and had approximately $50 \%$ mortality.

Regarding the history of the property, the producer reported that fish from the six cages came from the same fry supplier and were treated with antibiotics and disinfectants, but the disease was not controlled and mortalities continued to occur.

Ten fish from the finishing phase (average weight $461.2 \pm 52.4 \mathrm{~g}$ and standard length of $21.8 \pm 1.8 \mathrm{~cm}$ ) showing gill and internal organ pallor, skin darkening, tegument hemorrhage, and aqueous blood were sampled. Except for fish used for research on ectoparasites, all the others were submitted to euthanasia by deepening the anesthetic plane with benzocaine $\left(0.1 \mathrm{~g} \mathrm{~L}^{-1}\right)$. Samples of blood were collected by puncturing the caudal vessel. Tissue samples from the gills, liver, spleen, kidney, heart and intestine were also collected for histopathology.

\subsection{Microbiological analysis}

For microbiological analysis, fish were washed in water and disinfected with 70\% alcohol, and necropsy was done aseptically in microbiological flow (Bio Seg ${ }^{\oplus}$ 12, Veco, São Paulo, Brazil). The cranial kidney was perforated with a sterile platinum loop that was inoculated on a tryptone soya agar (Oxoid, Hampshire, United Kingdom) and maintained for $48 \mathrm{~h}$ in a microbiological incubator (Quimis ${ }^{\circledR}$, São Paulo, Brazil) adjusted to $30^{\circ} \mathrm{C}$.

\subsection{Parasitological analysis: endo and ectoparasites}

Skin and gill scrapings were made with glass slides to evaluate the ectoparasites alive. The fresh smears were analyzed under a microscope (Nikon ${ }^{\circledast}$ E200, Tokyo, Japan).
Fish were necropsied for observation of organ alterations. The intestine was opened and the contents spread over glass slides for macroand microscopic analysis of endoparasites.

\subsection{Hematological analysis: hematocrit, blood smears and scanning electron microscopy}

Hematocrit (\%) was measured using the microhematocrit technique described by Goldenfarb et al. (1971).

Smears were made with total blood, and samples were stained with May Grünwald-Giemsa-Wright (MGGW). The extensions were evaluated under optical microscopy (Nikon ${ }^{\circledR}$ E200, Tokyo, Japan) at $100 \times$ magnification.

For scanning electron microscopy (SEM), the total blood of infected animals $(n=2)$ was collected and fixed in $3 \%$ glutaraldehyde solution, then buffered with $0.1 \mathrm{M}$ potassium phosphate at $\mathrm{pH} 7.4$ for $48 \mathrm{~h}$. Subsequently, the samples were post-fixed in $1 \%$ osmium tetroxide solution for $4 \mathrm{~h}$, washed in the buffer solution and dehydrated gradually in ethyl alcohol. The material was critical-dried (EMS 850, Electron Microscopy Sciences, Pennsylvania, USA), stubs-mounted and impregnated with palladium-gold. Then, the samples were observed and electron-micrographed in a JEOL JSM 5410 (Jeol, Tokyo, Japan) scanning electron microscope operated at $15 \mathrm{kV}$.

\subsection{Morphometric and morphologic analysis of the Trypanosoma}

After staining, the photographs of parasites in blood were measured ( $n=50$ ) with Image-Pro Plus 4.1 software (Media Cybernetics, Silver Springs, Maryland, USA). The following parameters were measured: body length (BL), total length (TL), body width (BW), nucleus length $(\mathrm{NL})$, nucleus width $(\mathrm{NW})$, distance between the anterior portion and the nucleus (AN), distance between the posterior portion and the nucleus (PN), distance between nucleus and kinetoplast (NK), distance between the kinetoplast and anterior portion (KA), and distance between the kinetoplast and posterior portion (KP).

\subsection{Metagenomic DNA extraction, PCR and sequencing}

Approximately $500 \mu \mathrm{L}$ of blood was collected $(n=2)$ and immediately stored in liquid nitrogen until DNA extraction, which was performed with the "DNeasy Blood \& Tissue" (Qiagen, CA, EUA) kit according to the manufacturer's instructions. PCR was performed using the following specific primers for the 18S rDNA gene of trypanosomes: B (5' CGAACAACTGCCCTATCAGC 3') and I (5' GACTACAATGGTCTC TAATC $3^{\prime}$ ) generating a fragment of approximately 900 bp (Hamilton, 2003). The PCR reaction was performed using $10 \mathrm{ng}$ of DNA in a reaction containing $1.25 \mathrm{mM} \mathrm{MgCl}_{2}, 0.2 \mathrm{mM}$ dNTPs, $1 \mathrm{U}$ of Taq DNA polymerase enzyme (Invitrogen), PCR solution buffer $(1 \times)$ (Invitrogen), and $7 \mathrm{pmol}$ of each primer. The reaction was conducted under the following conditions: initial denaturation at $95^{\circ} \mathrm{C}$ for $5 \mathrm{~min}$, 35 cycles of $95^{\circ} \mathrm{C}$ for $1 \mathrm{~min}, 50^{\circ} \mathrm{C}$ for $1 \mathrm{~min}, 72^{\circ} \mathrm{C}$ for $2 \mathrm{~min}$ and final extension for $10 \mathrm{~min}$ at $72^{\circ} \mathrm{C}$. The amplicons were purified with the "MinElute ${ }^{\circledast}$ PCR Purification" kit (Qiagen, CA, USA) and sequenced on the ABI 3730 XL DNA Analyzer (Applied Biosystems, Foster City, CA) with the "DNA Sequencing-Big Dye Terminator Cycle Sequencing Ready ABI Prism" kit, Version 3. The sequences obtained were submitted to GenBank (GenBank accession nos. KX866927.1 and KX866929.1) and compared to those already deposited using Megablast.

\subsection{Histopathological analysis}

Samples from gills, liver, spleen, kidney, heart and intestine were collected $(n=3)$ to describe histopathological alterations. Tissues were preserved in $10 \%$ buffered formalin for $24 \mathrm{~h}$ and then transferred to different series of alcohol concentrations, cleared in xylene and 
embedded in paraffin wax following conventional histological processing. Sections were cut at 4-6 $4 \mathrm{~m}$ thickness in microtome and then stained with hematoxylin-eosin and mounted in Entellan. Photomicrographs were taken by computer with the Motic Images Plus 2.0 program (Nikon ${ }^{\circledR}$ E200, Tokyo, Japan).

\section{Results}

\subsection{Microbiological analysis}

The results of the bacterial growth in non-selective medium indicated that the fish were not infected by any bacteria.

\subsection{Parasitological analysis: endo and ectoparasites}

Scraping of the skin and gills revealed the massive presence of kinetoplastids. No other parasites were identified on the scrapings, and no endoparasites were observed on stomach and intestine of fish. No leeches were found in any of the evaluated hosts.

\subsection{Hematological analysis: hematocrit, blood smears and scanning electron microscopy}

Mean values of hematocrit were $8.56 \pm 2.79 \%$. Protozoa of Trypanosoma genus in trypomastigote form were observed on the blood smears of $100 \%$ of fish analyzed (Video 1). A massive number of parasites was observed in the blood smears (Fig. 1A) and in scanning electron microscopy (Fig. 1B); the number of parasites was clearly higher than the number of red blood cells present in the animal's blood.

\subsection{Morphometric and morphologic analysis of the Trypanosoma}

Hemoflagellates showed small morphological variations, with a short and thin body, similar in size to the erythrocytes, although some parasites were slightly larger. The cytoplasm was basophilic with oval nucleus and showed a loose chromatin that occupied the whole width of the parasite. The kinetoplast was rounded and well delimited, located at the posterior end of the body. A discrete undulating membrane was present in most hemoprotozoa, being more evident in some samples. The free flagella located at the anterior end of the body were observed only in some specimens.

The morphometric data of the parasites identified in the blood smears are shown in Table 1.

\subsection{Metagenomic DNA extraction, PCR and sequencing}

The 18S rDNA fragments presented a length of approximately $900 \mathrm{bp}$. When compared, all sequences were classified as belonging to the genus Trypanosoma; $100 \%$ coverage and $95 \%$ and $98 \%$ of identity from the sequences (GenBank accession nos. KX866927.1 and KX866929.1) were observed when compared with the sequences in the GenBank database (GenBank accession nos. AJ620556.1 and DQ016618.1), respectively.

\subsection{Histopathological analyses}

Histological examination indicated the presence of Trypanosoma sp. in all organs analyzed.

\subsubsection{Gill}

A large number of Trypanosoma were observed in the efferent and afferent vessels of the gills (Fig. 2A). Parasites were also found in the secondary lamellae (Fig. 2B), which are structures of the lamellar arterioles through which the parasite arrived. Furthermore, trypanosomes and cellular debris from the gill tissue were found in several areas analyzed (Fig. 2C).

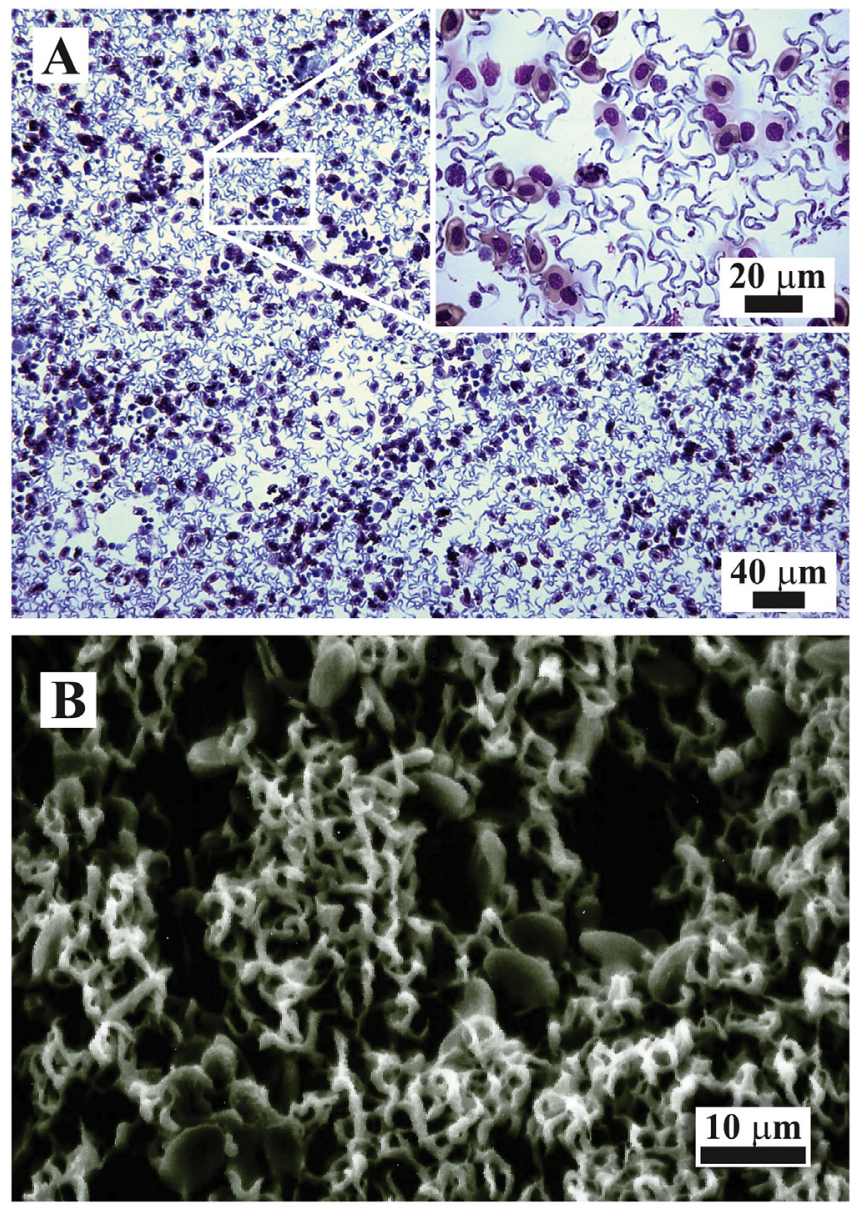

Fig. 1. Blood extension of Nile tilapia Oreochromis niloticus stained with the combination May Grünwald-Giemsa-Wright observed under optical microscopy and showing the large number of Trypanosoma sp. (A). Scanning electron microscopy photomicrograph showing the agglomerate of Trypanosoma sp. in the middle of the erythrocytes (B).

Table 1

Morphometrics of Trypanosoma sp. from Nile tilapia Oreochromis niloticus.

\begin{tabular}{lllllllllll}
\hline Measures $(\mu \mathrm{m})$ & BL & TL & BW & NL & NW & AN & PN & NK & KA & KP \\
\hline Average & 20.0 & 38.3 & 2.5 & 2.9 & 1.6 & 9.5 & 11.8 & 9.4 & 20.2 & 3.1 \\
Standard deviation & 3.0 & 4.3 & 0.5 & 0.4 & 0.2 & 1.7 & 1.9 & 1.1 & 2.7 & 0.5 \\
Minimum length & 13.2 & 28.4 & 1.3 & 2.0 & 1.1 & 6.0 & 6.1 & 7.3 & 14.7 & 2.0 \\
Maximum length & 24.8 & 46.6 & 3.5 & 3.7 & 2.4 & 13.3 & 14.8 & 12.2 & 26.5 & 4.2 \\
\hline
\end{tabular}

Body length (BL), total length (TL), body width (BW), nucleus length (NL), nucleus width (NW), distance between the anterior portion and the nucleus (AN), distance between the posterior portion and the nucleus (PN), distance between nucleus and kinetoplast (NK), distance between the kinetoplast and anterior portion (KA), distance between the kinetoplast and posterior portion (KP).

The integrity of the gill tissue was affected. Remarkable hyperplasia and hypertrophy of epithelial and mucus cells (Fig. 2D) were verified. Lamellar edema was also constantly observed (Fig. 2B,E). Several areas of the gill tissue showed severe lymphocyte inflammatory infiltration and moderate to complete fusion in the secondary lamellae (Fig. 2F). Another important finding was the presence of a severe agglomeration of mast cells across the base of the gill arch (Fig. 3). The mast cells were also found in moderate amounts in branchial lamellas, which was an uncommon finding.

\subsubsection{Liver and pancreas}

High numbers of Trypanosoma were present inside the portal veins, surrounded by the pancreatic tissue (Fig. 4A). The hepatic vessels also presented high Trypanosoma infestation. The liver showed high lipid 

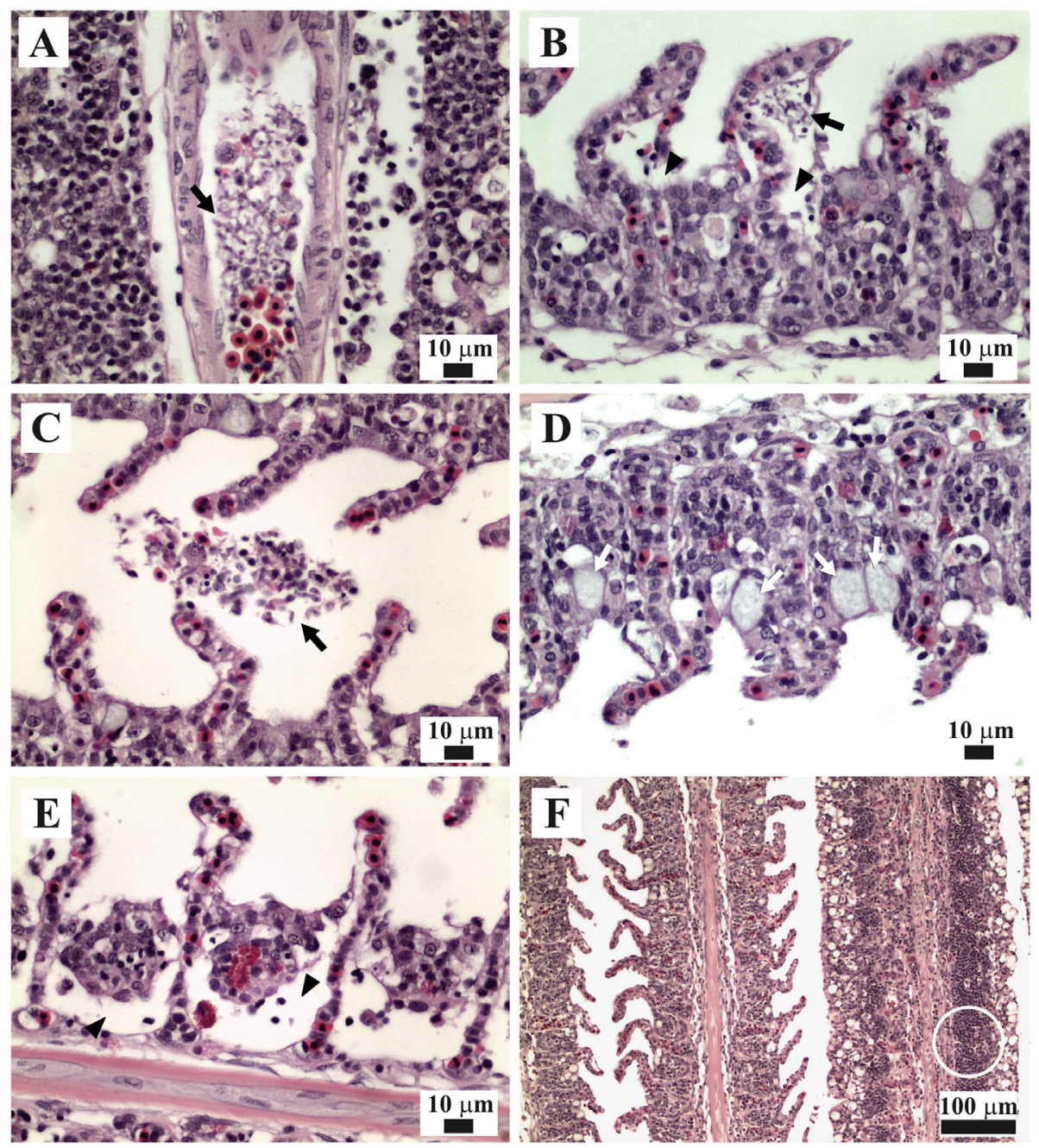

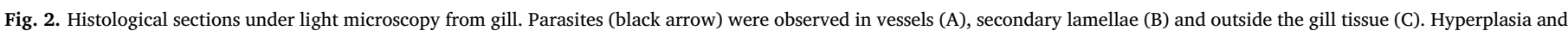

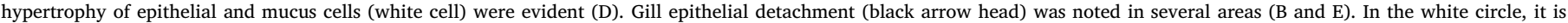
possible to observe severe lymphocyte inflammatory infiltration and moderate to complete fusion in the secondary lamellae (F).

degeneration (steatosis) (Fig. 4B). Multiple areas showed necrosis of the hepatic tissue, and the hepatopancreatic area was the most affected (Fig. 4C). The pancreas rupture was verified, with consequent extravasation of blood into the tissue (Fig. 4D).

\subsubsection{Spleen}

Vessel sections of this tissue showed high infestation by Trypanosoma (Fig. 5A). Histopathological sections of fish spleen showed multiple pigmented areas of melanomacrophage aggregation (Fig. 5B).

\subsubsection{Kidney}

The hematopoietic tissue of the kidney and interlobular blood vessels showed a high number of Trypanosoma (Fig. 6A). Multifocal pigmented areas of melanomacrophage aggregation were also observed in the kidney tissue (Fig. 6B). Furthermore, interstitial edema, inflammatory infiltrate and multiple areas of renal tubule degeneration, characterized by eosinophilic tinctorial change in the tubule cells and cytoplasmic vacuolation, were noted very close to the parasites (Fig. 6B, C).

\subsubsection{Other organs}

A high parasitism by Trypanosoma was verified inside the heart chambers (Fig. 7A).

The parasite was found inside the vessels in gut tissue (Fig. 7B). In some regions of the intestine, moderate infiltration of mast cells surrounding the vessel containing the parasite (Fig. 7B) was observed.

\section{Discussion}

Reports of trypanosomiasis in fish production are scarce, and based on an extensive literature review, this is the first report of trypanosomiasis affecting Nile tilapia in South America.

The report of a massive number of kinetoplastids of the genus Trypanosoma in skin and gills is unusual and probably occurred in this case due to the presence of the highly infected blood in the scraping. Both organs have small vessels, and their rupture during the procedure may allow for the extravasation of blood and, consequently, of the parasite. Although different kinetoplastids may live on the body surface (Woo, 2003), it is a consensus in the literature that the parasites are transmitted by leeches (Karlsbakk et al., 2005); however, these vectors were not found on analyzed fish. Other studies also did not find the vector in the parasitized fish, either in wild (Ferreira and AvenantOldewage, 2013) or cultivated hosts (Chong, 2005). The main hypothesis is that the infection may have occurred in another early life stage of Nile tilapia, which is carried out in earth ponds. Thus, the disease developed when fish were grown on net cages in a highly intensive environment, which is considered one of the most stressful factors in fish farming. This hypothesis is also based on the owner's history traceability, which indicated that the six cages affected were from the same fingerlings supplier. 


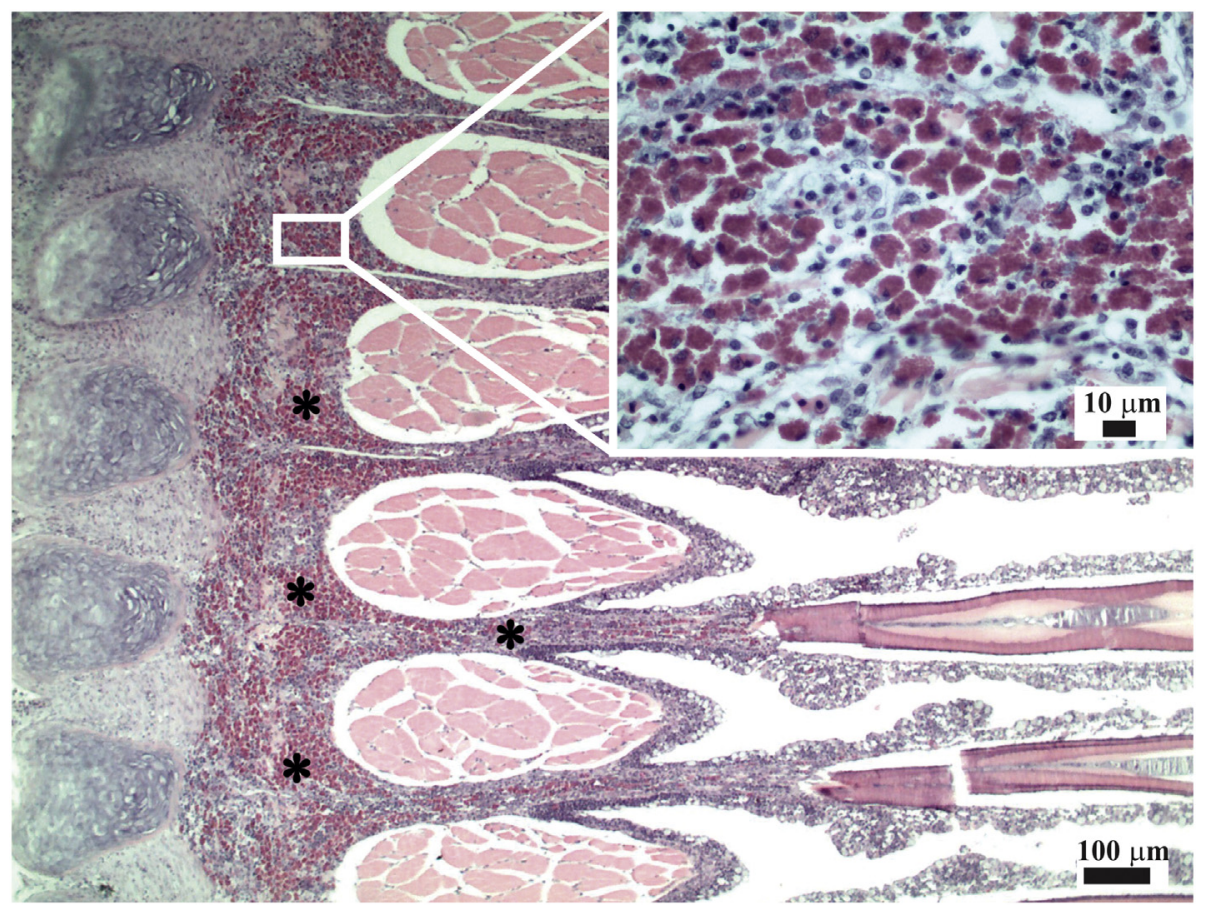

Fig. 3. Histological sections under light microscopy from gill. The massive presence of mast cells can be observed in asterisks and in the zoom image.

Numerous articles have described the morphology of trypanosomes in freshwater fish (Grögl et al., 1980, Pádua et al., 2011, Reda, 2011; Fujimoto et al., 2013; Molina et al., 2016), including hosts of the genus Oreochromis (Davies et al., 2005); however, the morphometric results found in this study indicated that there is no similarity with previous studies. This variance among studies may be due to the great diversity of trypanosome species and to the pleomorphism of these parasites (Gibson et al., 2005). The presence of Trypanosoma sp. in the evaluated fish was confirmed after comparing the nucleotide sequences obtained with those contained in the GenBank database; however, further studies will be required to identify and describe the species.

The gill and internal organ pallor, skin darkening, tegument hemorrhage and aqueous blood found in this study were similar to those alterations identified by Osman et al. (2009) in wild African catfish infected by trypanosomiasis. A significant decrease was observed in the percentage of hematocrit $(8.56 \pm 2.79 \%)$, which was about three times lower than the reference value of hematocrit in healthy Nile tilapia (31.42 $\pm 4.72 \%$ ) (Tavares-Dias et al., 2000; Azevedo et al., 2006; Yildiz et al., 2006; Sebastião et al., 2011). This alteration is due to anemia caused by the hemolytic crises in which the erythrocytes are destroyed (Igbokwe and Mohammed, 1991), leading to intense alteration of the hematological profile. This event hinders the osmoregulation and the transport of nutrients, resulting in debilitated fish and high mortality (Dykova and Lom, 1979; Woo, 2003; Shahi
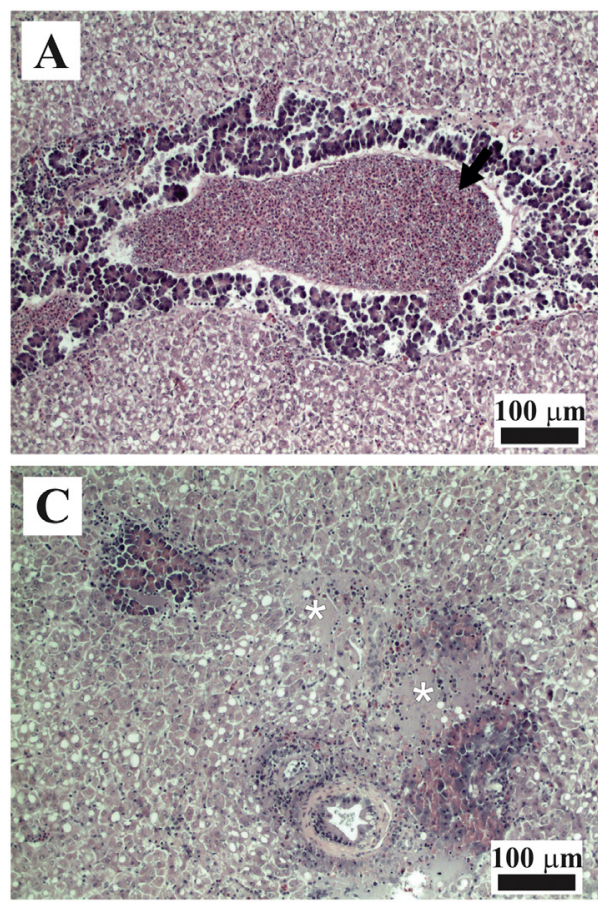
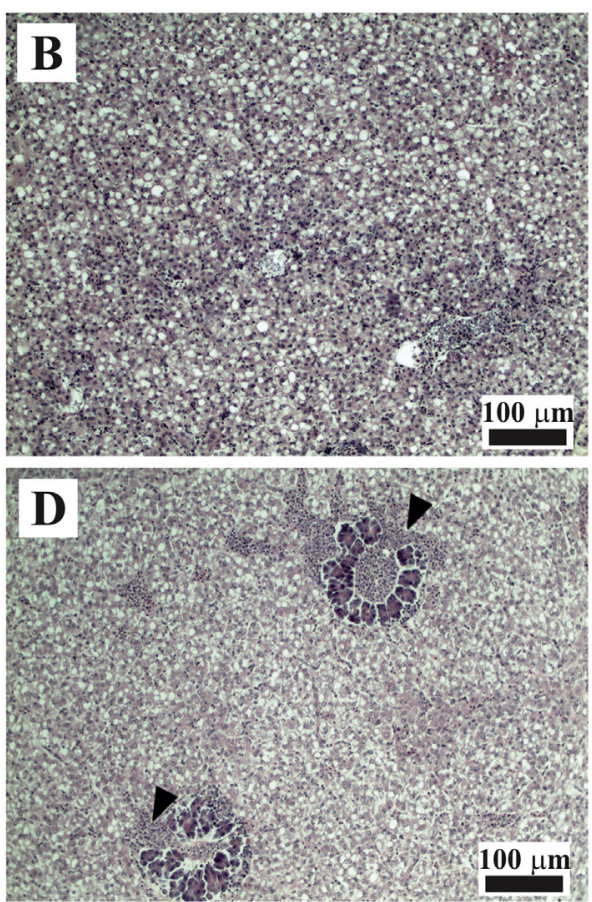

Fig. 4. Histological sections under light microscopy from liver and pancreas. In the black arrow were observed high numbers of Trypanosoma sp. inside the portal veins (A). Lipid degeneration (B, C and D) and several areas of necrosis in the hepatopancreatic tissue were evident (white asterisk) (C). The pancreas rupture was verified with extravasation of the blood (black arrow head) (D). 

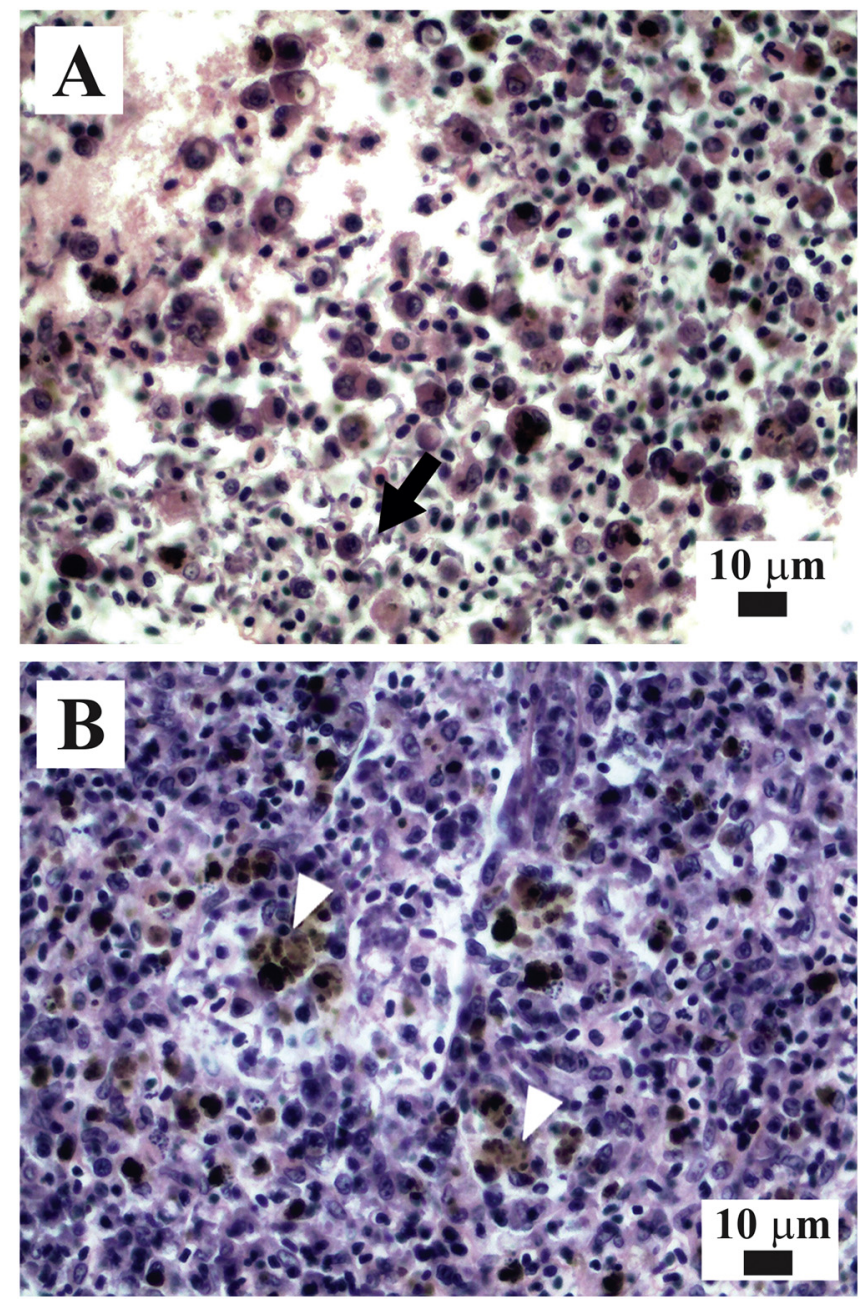

Fig. 5. Histological sections under light microscopy from spleen. In the black arrow it was possible to observe high infestation by Trypanosoma sp. (A). Multiple pigmented areas of melanomacrophage aggregation (white arrow head) (B).

et al., 2013). These changes are directly related to the pathology caused by the high infestation by Trypanosoma sp.

Regarding the pathological alterations caused by Trypanosoma sp., all organs presented a different level of pathology verified along with the systemic presence of Trypanosoma sp. in small and large vessels. In the gill, a set of changes was observed that can severely affect fish homeostasis, ionic impairing, and gaseous and nitrogen excretion. An unusual number of mast cells was found in the gill and in the gut of parasitized fish. Some authors have described the mast cells as a central component of defense against infections, and it has also been suggested that they contribute to the inflammatory process in teleost fish (Paulsen, 2001; Penissi et al., 2003). The massive presence of mast cells in the intestines and gills of infected fish (Dezfuli and Giari, 2008; Sfacteria et al., 2015; Gallani et al., 2016) indicates that mast cells may be an important mechanism of protection in cases of trypanosomiasis.

Multifocal areas of melanomacrophages, especially around vessels infested with trypanosomes, were commonly found in the liver, pancreas, spleen and kidney. Studies have shown the association of melanomacrotic centers with a range of bacteria (Gregori et al., 2014; Pirarat et al., 2016) and parasites (Székely et al., 2015, Ventura et al., 2016), but there is scarce information in cases of trypanosomiasis. The functions attributed to the melanomacrophage centers are the storage of phospholipids and cellular iron after excessive erythrocyte breakdown as well as deposition of resistant pathogens such as bacterial and parasitic spores (Thiyagarajah et al., 1998; Estrada and García, 1991; Agius and Roberts, 2003). In this case, the characteristic brown/golden
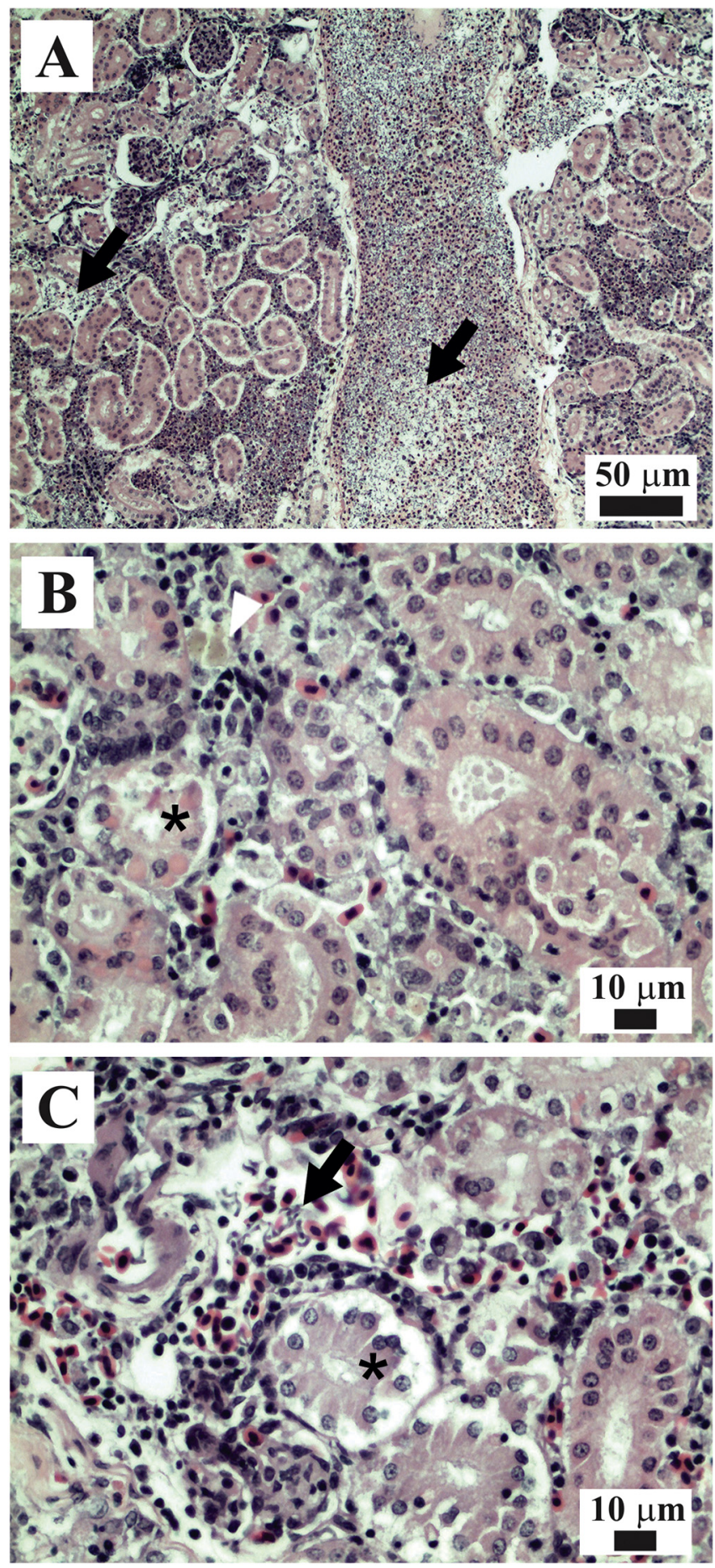

Fig. 6. Histological sections under light microscopy from kidney. The hematopoietic tissue of kidney and interlobular blood vessels showed a high number of Trypanosoma sp. (black arrow) (A). Multifocal pigmented areas of melanomacrophage aggregation were observed in the kidney tissue (white arrow head) (B). In the black asterisk (B and C), interstitial edema, inflammatory infiltrate and multiple areas of renal tubules degeneration characterized by eosinophilic tinctorial change in the tubule cells and cytoplasmic vacuolation were noted very close to the parasites (black arrow).

color is suggestive of hemosiderin accumulation in melanomacrophagous centers. Hemosiderin is a brown pigment containing a protein and an iron (ferric) component and can be present in considerable quantities under certain conditions, such as hemolytic anemia (Agius and Roberts, 2003). Thus, the disease caused by Trypanosoma sp. is directly related to anemia and, consequently, to the diffusion of 

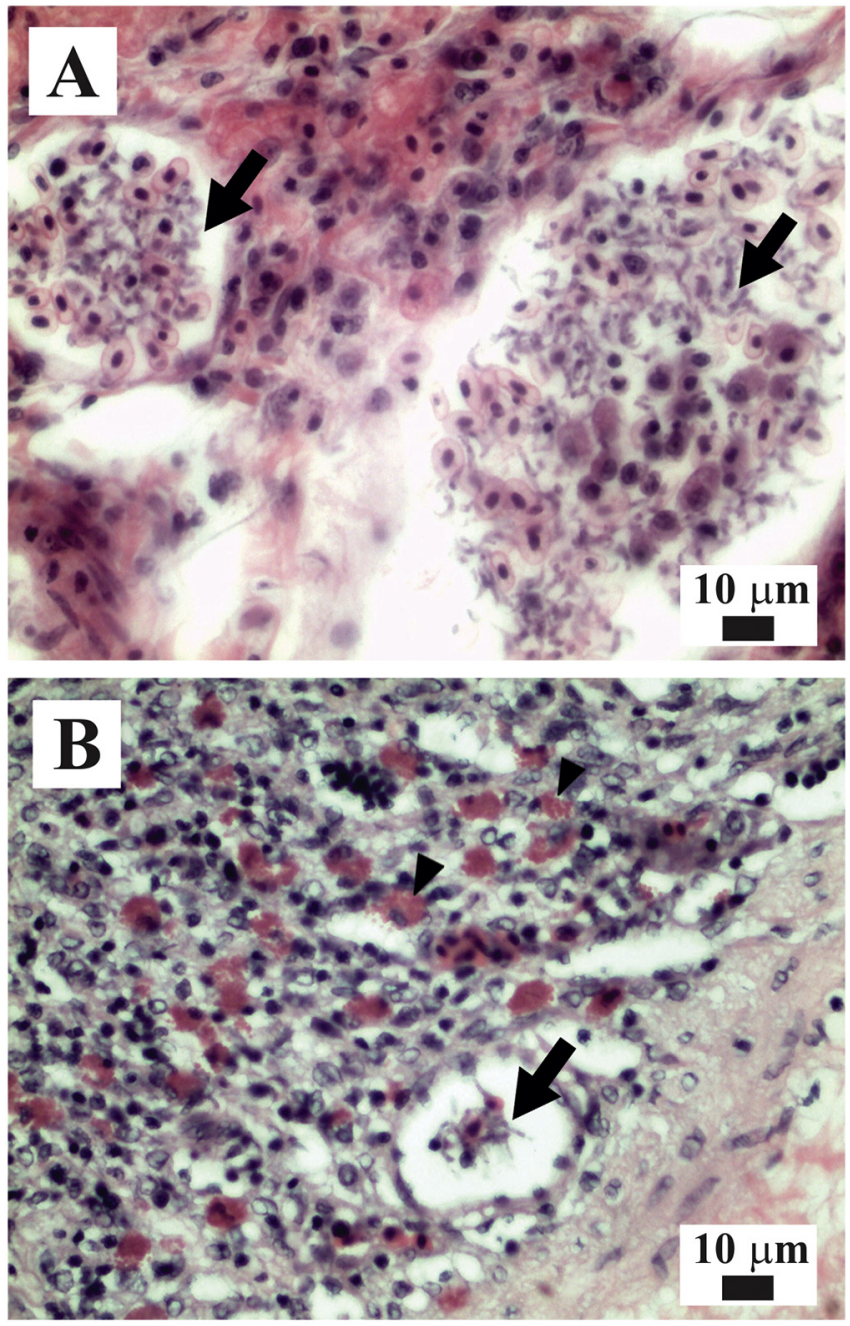

Fig. 7. Histological sections under light microscopy from heart and gut. A high parasitism by Trypanosoma sp. (black arrow) was verified inside the heart chambers (A). The parasite was found inside the vessels in the gut tissue (black arrow) and some regions of the intestine moderate infiltration of mast cells surrounding the vessel containing the parasite (black arrow head) was observed (B).

melanomacrophagous centers in the evaluated organs. Chong (2005) described the same pathogenesis in the spleen of marine fish Epinephelus areolatus infected by Trypanosoma sp., corroborating the findings of this study.

According to the fish farmer's history, even with the fish undergoing treatments, the disease was not controlled, indicating that the etiology was unusual and not related to pathogens already known in aquaculture, such as bacteria. Antibiotic treatment may have prevented a secondary infection, since bacteria were not found in fish that were highly susceptible due to intense parasitism and systemic alteration of the organs. In fact, even a combination of antibiotics, such as penicillin, streptomycin and amphotericin B, has no effect against Trypanosoma (Woo, 2003). Despite intensive aquaculture production, it is alarming that to date there are few legalized antiparasitics for treatment; therefore, the incorrect and indiscriminate use of chemotherapeutics is common. Although there are extensive studies on the treatment of trypanosomes in mammals, this information is scarce in the treatment of fish, with isometamidium chloride (suramin), crystal violet, diminazene aceturate (berenil) and quinapyramine chloride and sulfate (antrycide) being the most commonly used treatments (Woo, 2003). Vaccination for the control of Trypanosoma is possible (Woo, 1981; Overath et al., 1999), but only for experimental use. Thus, the prophylactic measures of elimination of the intermediate host, good management practices and traceability are still the most indicated sanitary measures in these circumstances.

This study brings the first identification, characterization and pathological evaluation of trypanosomiasis affecting Nile tilapia in South America. The authors warn of possible new cases of trypanosomiasis in aquaculture and indicate the blood smear as a more common tool for diagnosis of fish in mortality outbreaks. The authors encourage colleagues to follow research in this area, in which there is a shortage of information.

Supplementary data to this article can be found online at https:// doi.org/10.1016/j.aquaculture.2018.02.002.

\section{References}

Agius, C., Roberts, R.J., 2003. Melano-macrophage centres and their role in fish pathology. J. Fish Dis. 26, 499-509.

Azevedo, T.M.P., Martins, M.L., Yamashita, M.M., Francisco, C.J., 2006. Haematology of Oreochromis niloticus: comparison between fish maintained in a fish farm associated with pigs and in fee fishing in the valley of Tijucas river, Santa Catarina, Brazil. Bol. Inst. Pesca. 32, 41-49.

Chong, R.S.M., 2005. Trypanosomiasis in cultured Epinephelus areolatus. Bull. Eur. Assoc. Fish. Pathol. 25, 32.

Corrêa, L.L., Oliveira, M.S.B., Tavares-Dias, M., Ceccarelli, P.S., 2016. Infections of Hypostomus spp. by Trypanosoma spp. and leeches: a study of hematology and record of these hirudineans as potential vectors of these hemoflagellates. Rev. Bras. Parasitol. Vet. http://dx.doi.org/10.1590/S1984-29612016049.

D'Agosto, M., da Serra-Freire, N.M., 1993. Estádios evolutivos de tripanossomas de Hipostomus punctatus Valenciennes (Osteichthyes, Loricariidae) em infecção natural de Batracobdella gemmata Blanchard (Hirudinea, Glossiphoniidae). Rev. Bras. Zool. 10. http://dx.doi.org/10.1590/S0101-81751993000300008.

Davies, A., Gibson, W., Ferris, V., Basson, L., Smit, N., 2005. Two genotypic groups of morphologically similar fish trypanosomes from the Okavango Delta, Botswana. Dis. Aquat. Org. 66, 215-220. http://dx.doi.org/10.3354/dao066215.

Dezfuli, B.S., Giari, L., 2008. Mast cells in the gills and intestines of naturally infected fish: evidence of migration and degranulation. J. Fish Dis. 31, 845-852. http://dx.doi.org/ 10.1111/j.1365-2761.2008.00961.x.

Dykova, I., Lom, J., 1979. Histopathological changes in Trypanosoma danilewskyi Laveran \& Mesnil, 1904 and Trypanoplasma borelli Laveran \& Mesnil, 1902, infections of goldfish, Carassiw auratus (L.). J. Fish Dis. 2, 381-390. http://dx.doi.org/10.1111/j. 1365-2761.1979.tb00390.x.

Eiras, J.C., Rego, A.A., Pavanelli, G.C., 1989. Trypanosoma guairaensis sp. n. (Protozoa, Kinetoplastida) parasita de Megaloancistrus aculeatus (Perugia, 1891) (Pisces, Loricariidae). Mem. Inst. Oswaldo Cruz 84, 389-392. http://dx.doi.org/10.1590/ S0074-02761989000300015.

Eiras, J.C., Rego, A.A., Pavanelli, G.C., 1990. Trypanosoma nupelianus sp. n. (Protozoa, Kinetoplastida) parasitizing Rhinelepis aspera (Osteichthyes, Loricariidae) from Paraná river, Brazil. Mem. Inst. Oswaldo Cruz 85, 183-184. http://dx.doi.org/10. 1590/S0074-02761990000200006.

Estrada, R.R., García, P.B., 1991. Atlas de Histopatologia. Progresso, México.

Fermino, B.R., Paiva, F., Soares, P., Tavares, L.E.R., Viola, L.B., Ferreira, R.C., BoteroArias, R., de-Paula, C.D., Campaner, M., Takata, C.S.A., Teixeira, M.M.G., Camargo, E.P., 2015. Field and experimental evidence of a new caiman trypanosome species closely phylogenetically related to fish trypanosomes and transmitted by leeches. Int. J. Parasitol. 4, 368-378. http://dx.doi.org/10.1016/j.ijppaw.2015.10.005.

Ferreira, M.L., Avenant-Oldewage, A., 2013. Notes on the occurrence of Trypanosoma sp. (Kinetoplastida: Trypanosomatidae) in freshwater fishes from South Africa. Onderstepoort J. Vet. Res. 80. http://dx.doi.org/10.4102/ojvr.v80i1.529.

Fink, I.R., Ribeiro, C.M.S., Forlenza, M., Taverne-Thiele, A., Rombout, J.H.W.M., Savelkoul, H.F.J., Wiegertjes, G.F., 2015. Immune-relevant thrombocytes of common carp undergo parasite-induced nitric oxide-mediated apoptosis. Dev. Comp. Immunol. 50, 146-154. http://dx.doi.org/10.1016/j.dci.2015.02.008.

Fujimoto, R.Y., Neves, M.S., Santos, R.F.B., Souza, N.C., do Couto, M.V., Lopes, J.N.S. Diniz, D.G., Eiras, J.C., 2013. Morphological and hematological studies of Trypanosoma spp. infecting ornamental armored catfish from Guamá River-PA, Brazil. An. Acad. Bras. Cienc. 85, 1149-1156. http://dx.doi.org/10.1590/S0001 37652013005000039.

Gallani, S.U., Sebastião, F. de A., Valladão, G.M.R., Boaratti, A.Z., Pilarski, F., 2016. Pathogenesis of mixed infection by Spironucleus sp. and Citrobacter freundii in freshwater angelfish Pterophyllum scalare. Microb. Pathog. 100, 119-123. http://dx.doi. org /10.1016/j.micpath.2016.09.002.

Gibson, W.C., Lom, J., Pecková, H., Ferris, V.R., Hamilton, P.B., 2005. Phylogenetic analysis of freshwater fish trypanosomes from Europe using ssu rRNA gene sequences and random amplification of polymorphic DNA. Parasitology 130, 405-412. http:// dx.doi.org/10.1017/S0031182004006778.

Goldenfarb, P.B., Bowyer, F.P., Hall, E., Brosious, E., 1971. Reproducibility in the hematology laboratory: the microhematocrit determination. Am. J. Clin. Pathol. 56 35-39.

Gregori, M., Miragliotta, V., Leotta, R., Cecchini, S., Prearo, M., Abramo, F., 2014. Morphometric evaluation of interrenal gland and kidney macrophages aggregates in normal healthy rainbow trout (Oncorhynchus mykiss) and after bacterial challenge with Yersinia ruckeri. Vet. Med. Int. 2014, 1-7. http://dx.doi.org/10.1155/2014/ 
210625.

Grögl, M., Marinkelle, C.J., Suarez, M.F., de Sanchez, N., Guhl, F., 1980. Trypanosoma magdalenae sp. n (Protozoa: Kinetoplastida) from a freshwater teleost, Petenia kraussii, in Colombia. J. Parasitol. 66, 1022-1026.

Hamid, S.H.A., Babiker, E.M., 2011. Prevalence of trypanosome infection in Oreochromis niloticus and Clarias lazera from fish farms and reservoir of Jebel Aulia Dam in Sudan. World's Vet. J. 1, 14-16.

Hamilton, P.B., 2003. Investigations in Trypanosome Diversity and Evolution Using Molecular Phylogenetic Analysis. University of Bristol, School of Biological Sciences, Bristol (PhD thesis).

Hayes, P.M., Lawton, S.P., Smit, N.J., Gibson, W.C., Davies, A.J., 2014. Morphological and molecular characterization of a marine fish trypanosome from South Africa, in cluding its development in a leech vector. Parasit. Vectors 7, 50. http://dx.doi.org/ 10.1186/1756-3305-7-50

Igbokwe, I.O., Mohammed, A., 1991. The reticulocyte response to the anaemia in goats caused by experimental Trypanosoma brucei infection. Vet. Res. Commun. 15, 373-377.

Islam, A.K.M.N., Woo, P.T.K., 1991. Anemia and its mechanism in goldfish Carassius auratus infected with Trypanosoma danilewskyi. Dis. Aquat. Org. 11, 37-43.

Karlsbakk, E., Haugen, E., Nylund, A., 2005. Morphology and aspects of growth of a trypanosome transmitted by the marine leech Johanssonia arctica (Piscicolidae) from Northern Norway. Folia Parasitol. 52, 209-215.

Khan, R.A., 1977. Susceptibility of marine fish to trypanosomes. Can. J. Zool. 55, 1235-1241.

Kovacevic, N., Hagen, M.O., Xie, J., Belosevic, M., 2015. The analysis of the acute phase response during the course of Trypanosoma carassii infection in the goldfish (Carassius auratus L.). Dev. Comp. Immunol. 53, 112-122. http://dx.doi.org/10.1016/j.dci. 2015.06.009.

Lemos, M., Souto-Padrón, T., 2014. Isolation and in vitro maintenance of trypanosomes from naturally infected and commercially important Brazilian fish. J. Parasitol. 100, 687-691. http://dx.doi.org/10.1645/14-502.1.

Lemos, M., Souza, C.S.F., da Costa, S.C.G., Souto-Padrón, T., D'Agosto, M., 2013. Isolation and in vitro culture of trypanosomes from Leptodactylus ocellatus from the Atlantic forest in a new experimental culture medium. J. Parasitol. 99, 164-167. http://dx. doi.org/10.1645/GE-2949.1.

Lemos, M., Fermino, B.R., Simas-Rodrigues, C., Hoffmann, L., Silva, R., Camargo, E.P., Teixeira, M.M.G., Souto-Padrón, T., 2015. Phylogenetic and morphological characterization of trypanosomes from Brazilian armoured catfishes and leeches reveal high species diversity, mixed infections and a new fish trypanosome species. Parasit. Vectors 8. http://dx.doi.org/10.1186/s13071-015-1193-7.

Lima, L., Espinosa-Álvarez, O., Ortiz, P.A., Trejo-Varón, J.A., Carranza, J.C., Pinto, C.M., Serrano, M.G., Buck, G.A., Camargo, E.P., Teixeira, M.M.G., 2015. Genetic diversity of Trypanosoma cruzi in bats, and multilocus phylogenetic and phylogeographical analyses supporting Tcbat as an independent DTU (discrete typing unit). Acta Trop. 151, 166-177. http://dx.doi.org/10.1016/j.actatropica.2015.07.015.

Lourenço, K.G., Claudiano, G.S., Eto, S.F., Aguinaga, J.Y., Marcusso, P.F., Salvador, R., de Moraes, J.R.E., de Moraes, F.R., 2014. Hemoparasite and hematological parameters in Nile tilapia. Comp. Clin. Pathol. 23, 437-441. http://dx.doi.org/10.1007/s00580012-1638-8.

Marcili, A., da Costa, A.P., Soares, H.S., Acosta, I.C.L., de Lima, J.T.R., Minervino, A.H.H., Gennari, S.M., 2013. First report of Trypanosoma sp. in spectacled caiman (Caiman crocodilus): morphological and phylogenetic relationships. ISRN Parasitol. 2013, 1-7. http://dx.doi.org/10.5402/2013/328794.

Molina, J.P., Madi, R.R., Solferini, V.N., Ceccarelli, P.S., Pinheiro, H.P., Ueta, M.T., 2016. Trypanosomatids (Protozoa: Kinetoplastida) in three species of armored catfish from Mogi-Guaçu river, Pirassununga, São Paulo, Brazil. Rev. Bras. Parasitol. Vet. 25, 131-141. http://dx.doi.org/10.1590/S1984-29612016027.

Morillas, J., George-Nascimento, M., Valeria, H., Khan, R.A., 1987. Trypanosoma humboldti n. sp. from the Chilean catshark, Schroederichthys chilensis (Guichenot, 1848). J. Protozool. 34, 342-344.

Negm-Eldin, M.M., Davies, R.W., 1999. Simultaneous transmission of Trypanosoma mukasai, Babesiosoma mariae and Cyrilia nili to fish by the leech Batracobdelloides tricarinata. Dtsch. Tierarztl. Wochenschr. 106, 526-527.

Ooi, C.-P., Rotureau, B., Gribaldo, S., Georgikou, C., Julkowska, D., Blisnick, T., Perrot, S., Subota, I., Bastin, P., 2015. The flagellar arginine kinase in Trypanosoma brucei is important for infection in Tsetse flies. PLoS One 10, e0133676. http://dx.doi.org/10. 1371/journal.pone.0133676.

Osman, H.A.M., Fadel, N.G., Ali, A.T., 2009. Biochemical and histopathological alterations in catfish, Clarias gariepinus infected with trypanosomiasis with special reference to immunization. Egypt. J. Comp. Pathol. Clin. Pathol 22, 164-181.

Overath, P., Haag, J., Mameza, M.G., Lischke, A., 1999. Freshwater fish trypanosomes: definition of two types, host control by antibodies and lack of antigenic variation. Parasitology 119, 591-601.

de Pádua, S.B., Ishikawa, M.M., Satake, F., Jerônimo, G.T., Pilarski, F., 2011. First record of Trypanosoma sp. (Protozoa: Kinetoplastida) in tuvira (Gymnotus aff. inaequilabiatus) in the Pantanal wetland, Mato Grosso do Sul State, Brazil. Rev. Bras. Parasitol. Vet. 20, 85-87. http://dx.doi.org/10.1590/S1984-29612011000100019.

Paulsen, S., 2001. Selective staining and disintegration of intestinal eosinophilic granule cells in Atlantic salmon after intraperitoneal injection of the zinc chelator dithizone. J. Fish Biol. 58, 768-775. http://dx.doi.org/10.1006/jfbi.2000.1497.

Penissi, A.B., Rudolph, M.I., Piezzi, R.S., 2003. Role of mast cells in gastrointestinal mucosal defense. Biocell 27, 163-172.

Pirarat, N., Ooi, E.L., Thompson, K.D., Thinh, N.H., Maita, M., Katagiri, T., 2016 Examination of entry portal and pathogenesis of Edwardsiella ictaluri infection in striped catfish, Pangasianodon hypophthalmus. Aquaculture 464, 279-285. http://dx. doi.org/10.1016/j.aquaculture.2016.06.043.

Reda, E.S.A., 2011. A review of some ecto-and endo protozoan parasites infecting Sarotherodon galilaeus and Tilapia zillii from Damietta branch of river Nile. Egypt J. Amer. Sci. 7, 362-373.

Sebastião, F.A., Nomura, D., Sakabe, R., Pilarski, F., 2011. Hematology and productive performance of Nile tilapia (Oreochromis niloticus) naturally infected with Flavobacterium columnare. Braz. J. Microbiol. 42, 282-289.

Sfacteria, A., Brines, M., Blank, U., 2015. The mast cell plays a central role in the immune system of teleost fish. Mol. Immunol. 63, 3-8. http://dx.doi.org/10.1016/j.molimm. 2014.02.007.

Shahi, N., Yousuf, A.R., Rather, M.I., Ahmad, F., Yaseen, T., 2013. First report of blood parasites in fishes from Kashmir and their effect on the haematological profile. Open Vet. J. 3, 89-95.

Silva, V., Valenzuela, A., Ruiz, P., Oyarzún, C., 2005. Trypanosoma humboldti en Schroederichthys chilensis (Chondrichthyes, Elasmobranchii, Sscyliorhinidae) como indicador no destructivo de contaminacion. Gayana (Concepción) 69. http://dx.doi. org/10.4067/S0717-65382005000100020.

Su, Y., Feng, J., Jiang, J., Guo, Z., Liu, G., Xu, L., 2014. Trypanosoma epinepheli n. sp. (Kinetoplastida) from a farmed marine fish in China, the brown-marbled grouper (Epinephelus fuscoguttatus). Parasitol. Res. 113, 11-18. http://dx.doi.org/10.1007/ s00436-013-3626-6.

Svobodová, M., Weidinger, K., Peške, L., Volf, P., Votýpka, J., Voříšek, P., 2015 Trypanosomes and haemosporidia in the buzzard (Buteo buteo) and sparrowhawk (Accipiter nisus): factors affecting the prevalence of parasites. Parasitol. Res. 114, 551-560. http://dx.doi.org/10.1007/s00436-014-4217-x.

Székely, C., Cech, G., Chaudhary, A., Borzák, R., Singh, H.S., Molnár, K., 2015. Myxozoan infections of the three Indian major carps in fish ponds around Meerut, UP, India, with descriptions of three new species, Myxobolus basuhaldari sp. n., M. kalavatiae sp. n. and $M$. meerutensis sp. n., and the redescription of $M$. catlae and M. bhadrensis. Parasitol. Res. 114, 1301-1311. http://dx.doi.org/10.1007/s00436-014-4307-9.

Tavares-Dias, M., Schalch, S.H.C., Silva, E.D., Martins, M.L., Moraes, F.R., 2000. Características hematológicas de Oreochromis niloticus (Osteichthyes: Cichlidae) cultivada intensivamente em pesque-pague do município de Franca, SP, Brazil. Ars. Veterinária 16, 76-82.

Thiyagarajah, A., Hartley, W.R., Abdelghani, A., 1998. Hepatic hemosiderosis in buffalo fish (Ictiobus spp.). Mar. Environ. Res. 46, 203-207. http://dx.doi.org/10.1016/ S0141-1136(98)00015-4.

Ventura, A.S., Ishikawa, M.M., Gabriel, A.M. de A., Silbiger, H.L.N., Cavichiolo, F., Takemoto, R.M., 2016. Histopathology from liver of tuvira (Gymnotus spp.) parasitized by larvae of nematodes. Cienc. Rural 46, 1233-1239. http://dx.doi.org/10 1590/0103-8478cr20150881.

Wang, M., Yan, S., Wang, Y., Lun, Z.-R., Yang, T.-B., 2015. Occurrence of trypanosomiasis in net-cage cultured groupers (Cromileptes altivelis and Epinephelus fuscoguttatus) in Nanshan port of Sanya, Hainan province, China. Aquac. Res. 46, 1039-1043. http:// dx.doi.org/10.1111/are.12261.

Woo, P.T., 1981. Acquired immunity against Trypanosoma danilewskyi in goldfish, Carassius auratus. Parasitology 83, 343-346.

Woo, P.T.K., 2003. Cryptobia (Trypanoplasma) salmositica and salmonid cryptobiosis. J. Fish Dis. 26, 627-646.

Yildiz, H.Y., Köksal, G., Borazan, G., Benli, C.K., 2006. Nitrite-induced methemoglobinemia in Nile tilapia, Oreochromis niloticus. J. Appl. Ichthyol. 22, 427-429. http://dx. doi.org/10.1111/j.1439-0426.2006.00761.x. 